\title{
Contribution of environmental factors in the formation of biofilms by Alicyclobacillus acidoterrestris on surfaces of the orange juice industry
}

\author{
Tatiane Viana Dutra ${ }^{1}$ Daniela Biral do Prado ${ }^{(D)}$ Márcia Maria dos Anjos ${ }^{1}$ (D) \\ Miguel Machinski Junior ${ }^{4}$ Jane Martha Graton Mikcha ${ }^{3}$ Benício Alves de Abreu Filho (*) $^{*}$
}

\author{
${ }^{1}$ Programa de Pós-graduação em Ciência de Alimentos, Universidade Estadual de Maringá (UEM), Maringá, PR, Brasil. \\ ${ }^{2}$ Docente do curso de Nutrição do Centro Universitário Ingá (UNINGÁ), Maringá, PR, Brasil. \\ ${ }_{3}^{3}$ Departamento de Análises Clínicas e Biomedicina Universidade Estadual de Maringá (UEM), Maringá, PR, Brasil. \\ ${ }^{4}$ Departamento de Ciências Básicas da Saúde, Universidade Estadual de Maringá (UEM), 87020-900, Maringá, PR, Brasil. E-mail: \\ baafilho@uem.br. "Corresponding author.
}

\begin{abstract}
The objective of this study was to evaluate the effect of the initial microbial load, temperature and contact time on the biofilm formation of Alicyclobacillus acidoterrestris on stainless steel and natural food-grade rubber using orange juice as culture medium. The low initial load of $A$. acidoterrestris (2 log CFU/mL) led to biofilm formation on the stainless steel surface after $48 \mathrm{~h}$ of contact at $28{ }^{\circ} \mathrm{C}$ and after $24 \mathrm{~h}$ at $45^{\circ} \mathrm{C}$, and on natural food-grade rubber surface after $48 \mathrm{~h}$ of contact at both temperatures. The high initial microbial load (5 log CFU/ $m L$ ) led to biofilm formation on stainless steel after $4 \mathrm{~h}$ of contact at $28^{\circ} \mathrm{C}$ and $45^{\circ} \mathrm{C}$, while biofilm was formed on natural food-grade rubber after $8 \mathrm{~h}$ of contact at $28^{\circ} \mathrm{C}$ and $4 \mathrm{~h}$ at $45^{\circ} \mathrm{C}$. The microbial load also affected the presence of spores in biofilm, which was observed on both surfaces only at high initial loads of $A$. acidoterrestris.
\end{abstract}

Key words: concentrated orange juice, stainless steel, natural food-grade rubber, spores, biofilm.

Contribuição de fatores ambientais na formação de biofilmes por Alicyclobacillus acidoterrestris em superfícies da indústria de suco de laranja

RESUMO: O objetivo deste estudo foi avaliar o efeito da carga microbiana inicial, temperatura e tempo de contato na formação de biofilme de Alicyclobacillus acidoterrestris em aço inoxidável e borracha natural de qualidade alimentar utilizando suco de laranja como meio de cultura. A baixa carga inicial de A. acidoterrestris (2 $\log U F C / m L)$ levou à formação de biofilme na superficie do aço inoxidável após 48 h de contato a $28^{\circ} \mathrm{C}$ e após $24 \mathrm{~h}$ a $45^{\circ} \mathrm{C}$, e na superficie natural de borracha de qualidade alimentar após 48 h de contato nas duas temperaturas. A alta carga microbiana inicial (5 log UFC/mL) levou à formação de biofilme em aço inoxidável após 4 h de contato a $28{ }^{\circ} \mathrm{C} e 45^{\circ} \mathrm{C}$, enquanto o biofilme foi formado em borracha natural de qualidade alimentar após 8 h de contato a $28{ }^{\circ} \mathrm{C}$ e $4 \mathrm{~h}$ a $45^{\circ} \mathrm{C}$. A carga microbiana também afetou a presença de esporos no biofilme, o que foi observado em ambas as superficies apenas com altas cargas iniciais de A. acidoterrestris. Palavras-chave: suco concentrado de laranja, aço inoxidável, borracha natural de qualidade alimentar, esporos, biofilme.

\section{INTRODUCTION}

Brazil is currently the world's leading producer and exporter of concentrated orange juice. Concentrated orange juice has low water activity $(0.80$ - 0.83 ), low $\mathrm{pH}$ (3.5 to 4.0), a high concentration of soluble solids ( $\left.65^{\circ} \mathrm{Brix}\right)$, high viscosity, and low redox potential, which together with the heat treatment during the concentration process inhibit the multiplication of many spoilage and pathogenic microorganisms. However, bacteria of genus Alicyclobacillus spp. survive these environments and caused an unpleasant taste and odour in the juice, described as antiseptic or disinfectant due to the formation of 2,4-dibromophenol and 2-methoxyphenol (guaiacol) compounds, respectively (ORR et al., 2000; SMIT et al., 2011; STEYN et al., 2011).

Alicyclobacillus is a genus of spore-forming bacteria, Gram-positive that have already been found in soil, organic compost, manure, fruit surface, and acidic beverages (STEYN et al., 2011; TIANLII et al., 2014). The contamination of juices and processing environment with Alicyclobacillus spp. may occur during post-harvest without adequate cleaning of the fruits. This microorganism may still be present in the food industry in the form of biofilms (ANJOS et al., 2013). Biofilms are considered a complex and structured community of microorganisms, surrounded by an extracellular matrix of polysaccharides, adhered to each other and/or to a surface or interface 
(COSTERTON et al., 1995). These biofilms increase the cell's resistance to environmental stresses, reduce the efficiency of sanitizers, and bring economic losses to the food industry, as it can be a focus of food contamination (SIMÕES et al., 2010).

The objective of this study was to evaluate the effect of the initial inoculated microbial load (low - $2 \log$, or high - $5 \log$ ), processing temperatures ( 28 ${ }^{\circ} \mathrm{C}$ and $\left.45^{\circ} \mathrm{C}\right)$ and contact times $(0,4,8,24,48$, and $72 \mathrm{~h}$ ) on the biofilm formation of $A$. acidoterrestris on stainless steel and natural food-grade rubber surfaces using orange juice as culture medium.

\section{MATERIALS AND METHODS}

\section{Materials}

A. acidoterrestris CBMAI 0244T strain (DSMZ 3922, Deutsche Sammlung von Mikroorganismen und Zellkulturen, Germany) was used for the biofilm formation. The strain was stored in $30 \%$ glycerol at $-20{ }^{\circ} \mathrm{C}$ and activated in $3 \mathrm{~mL}$ of BAT broth (Bacillus acidoterrestris broth) at $45{ }^{\circ} \mathrm{C}$ for $24 \mathrm{~h}$.

The biofilm formation was evaluated in AISI 304\#4 stainless steel coupon $(8 \mathrm{~mm} \times 8 \mathrm{~mm}$ $\mathrm{x} 1 \mathrm{~mm}$ ) and a natural food-grade rubber surface ( $8 \mathrm{~mm} \times 8 \mathrm{~mm} \times 3 \mathrm{~mm}$ ), non-toxic, food-grade rubber, normally utilized as a fruit conveyor belt in food industries. Before each assay, the surfaces were rinsed with neutral detergent and distilled water, immersed in $70 \%(\mathrm{v} / \mathrm{v})$ ethanol for 1 hour at room temperature, rinsed again in distilled water, placed in microtubes, and sterilized at $121^{\circ} \mathrm{C}$ for 15 (FERNANDES et al., 2014).

Concentrated orange juice ( $\left.66^{\circ} \mathrm{Brix}\right)$ was reconstituted to $11^{\circ}$ Brix (aw 0.96, $\mathrm{pH} 4.0$ ) using sterile deionized water.

\section{Absence and control of microbial load}

The absence of Alicyclobacillus spp. vegetative cells and spores in the samples was previously investigated. In each sterile microtube were added one coupon, $900 \mathrm{uL}$ reconstituted orange juice and $100 \mathrm{uL}$ diluted culture. Two experiments were carried out: i) addition of $100 \mathrm{uL} \mathrm{A}$. acidoterrestris strains at a load of $2 \log \mathrm{CFU} / \mathrm{mL}$, and ii) addition of $100 \mathrm{uL}$ A. acidoterrestris strains at $5 \mathrm{log} \mathrm{CFU} /$ $\mathrm{mL}$. Subsequently, the microtubes were incubated at 28 and $45^{\circ} \mathrm{C}$. The analyses were performed after $0,4,8,24,48$, and $72 \mathrm{~h}$. After each inoculation, a control of $A$. acidoterrestris cell count on BAT agar was performed to confirm the initial microbial load. Plates were incubated at $45{ }^{\circ} \mathrm{C}$ for $24 \mathrm{~h}$.

\section{Biofilm formation}

The biofilm formation was assessed by the plate counting technique. At each time $(0,4,8,24,48$, $72 \mathrm{~h}$ ) and contact temperature $\left(28^{\circ} \mathrm{C}\right.$ and $\left.45^{\circ} \mathrm{C}\right)$, the stainless steel and natural food-grade rubber coupons were removed from the orange juice and transferred separately to microtubes containing $1.0 \mathrm{~mL}$ of $0.85 \%$ saline solution, remaining immersed for $1 \mathrm{~min}$ at rest to remove the planktonic cells. Then, each vial was immersed in $1.0 \mathrm{~mL}$ of $0.85 \%$ saline solution and subjected to ultrasound for $5 \mathrm{~min}$ to remove the sessile cells (ANJOS et al., 2013). For the spore counts, the coupons were subsequently subjected to a heat shock of $80^{\circ} \mathrm{C}$ for $10 \mathrm{~min}$, followed by plating on BAT agar and incubation at $45^{\circ} \mathrm{C}$ for $24 \mathrm{~h}$ (FERNANDES et al., 2014). The count was performed on BAT agar by drop plate method (HERIGSTAD et al., 2001). On each BAT agar plate was added three drop $(20 \mathrm{uL}$ each) of each dilution. The average of the counts was applied according to SWANSON et al., 1992. Each experiment was repeated three times.

\section{Statistical analyses}

All investigated variables were subjected to an analysis of variance (ANOVA). For each temperature, the contact times were compared using Tukey's test $(p<0.05)$. The results of vegetative cells counts were compared between the temperatures of $28{ }^{\circ} \mathrm{C}$ and $45^{\circ} \mathrm{C}$ using T-Student test $(\mathrm{p}<0.05)$. The same test also has been used to compare results of spore counts between temperatures of 28 and $45{ }^{\circ} \mathrm{C}$. In all cases, the statistic tests were applied separately for planktonic cells orange juice, sessile cells stainless steel, and sessile cells natural food-grade rubber, for each time. Statistical analysis was performed using the SISVAR program version 5.3 (FERREIRA, 2008).

\section{RESULTS}

Tables 1 and 2 show the results of low and high initial concentration, respectively, the $A$. acidoterrestris planktonic cells counts $(\log \mathrm{CFU} / \mathrm{mL})$ in orange juice, and the sessile cells counts (log CFU/ $\mathrm{cm}^{2}$ ) on stainless steel and natural food-grade rubber surfaces as a function of the time and temperature.

The low initial load of $A$. acidoterrestris (Table 1) led to biofilm formation on the stainless steel surface after $48 \mathrm{~h}$ of contact at $28^{\circ} \mathrm{C}$ and after $24 \mathrm{~h}$ at $45^{\circ} \mathrm{C}$. The highest biofilm formation $(\mathrm{P}<0.05)$ on stainless steel was observed after $72 \mathrm{~h}$ at $28^{\circ} \mathrm{C}$ and $24 \mathrm{~h}$ at $45^{\circ} \mathrm{C}$. After $72 \mathrm{~h}$ at $45^{\circ} \mathrm{C}$, a reduction of the $A$. acidoterrestris counts of more than one log cycle was observed. On the natural food-grade rubber surface, 
Table 1 - Mean Alicyclobacillus acidoterrestris count \pm standard deviation (SD) of planktonic cells $(\log \mathrm{CFU} / \mathrm{mL})$ and sessile cells $\left(\log \mathrm{CFU} / \mathrm{cm}^{2}\right)$ at initial inoculated load of $2 \log \mathrm{CFU} / \mathrm{mL}$.

\begin{tabular}{|c|c|c|c|c|c|c|c|c|c|c|c|c|}
\hline \multirow{3}{*}{$\begin{array}{l}\text { Time } \\
\text { (h) }\end{array}$} & \multicolumn{4}{|c|}{--------------Planktonic cells Orange juice------------ } & \multicolumn{4}{|c|}{------------Sessile cells Stainless steel---------- } & \multicolumn{4}{|c|}{----------------Sessile cells Rubber--------------- } \\
\hline & ------------28 & C------------ & $--------45^{\circ} \mathrm{C}$ & ----- & ---------28 ${ }^{\circ} \mathrm{C}$ & -------- & $---45^{\circ} \mathrm{C}$ & -------- & ---------28 ${ }^{\circ} \mathrm{C}$ & -------- & $------45^{\circ} \mathrm{C}$ & -------- \\
\hline & $\begin{array}{l}\text { Vegetative } \\
\text { cells }\end{array}$ & Spores & $\begin{array}{l}\text { Vegetative } \\
\text { cells }\end{array}$ & Spores & $\begin{array}{l}\text { Vegetative } \\
\text { cells }\end{array}$ & Spores & $\begin{array}{l}\text { Vegetative } \\
\text { cells }\end{array}$ & Spores & $\begin{array}{l}\text { Vegetative } \\
\text { cells }\end{array}$ & Spores & $\begin{array}{l}\text { Vegetative } \\
\text { cells }\end{array}$ & Spores \\
\hline 4 & $2.64 \pm 0.01^{\mathrm{cA}}$ & $<1.7^{* \mathrm{~b}}$ & $3.29 \pm 1.04^{\mathrm{bA}}$ & $<1.7^{\mathrm{b}}$ & $<3^{* *} \mathrm{c}$ & $<3$ & $<3^{\mathrm{c}}$ & $<3$ & $<3^{\mathrm{b}}$ & $<3$ & $<3^{\mathrm{b}}$ & $<3$ \\
\hline 8 & $2.65 \pm 0.00^{\mathrm{cB}}$ & $<1.7^{\mathrm{b}}$ & $4.20 \pm 0.00^{\mathrm{bA}}$ & $<1.7^{\mathrm{b}}$ & $<3^{\mathrm{c}}$ & $<3$ & $<3^{\mathrm{c}}$ & $<3$ & $<3^{\mathrm{b}}$ & $<3$ & $<3^{\mathrm{b}}$ & $<3$ \\
\hline 24 & $4.17 \pm 0.19^{\mathrm{bA}}$ & $<1.7^{\mathrm{b}}$ & $4.94 \pm 1.77^{\mathrm{aA}}$ & $<1.7^{\mathrm{b}}$ & $<3^{\mathrm{cB}}$ & $<3$ & $4.88 \pm 0.84^{\mathrm{aA}}$ & $<3$ & $<3^{\mathrm{b}}$ & $<3$ & $<3^{\mathrm{b}}$ & $<3$ \\
\hline 48 & $5.50 \pm 0.76^{\mathrm{aA}}$ & $2.7 \pm 0.00^{\mathrm{aA}}$ & $5.09 \pm 0.02^{\mathrm{aA}}$ & $\begin{array}{c}3.00 \pm 0 \\
00^{\mathrm{aA}}\end{array}$ & $3.73 \pm 0.39^{\mathrm{bA}}$ & $<3$ & $4.03 \pm 1.00^{\mathrm{a}, \mathrm{bA}}$ & $<3$ & $3.72 \pm 0.08^{\mathrm{aB}}$ & $<3$ & $4.73 \pm 0.01^{\mathrm{aA}}$ & $<3$ \\
\hline 72 & $5.40 \pm 0.69^{\mathrm{aA}}$ & $2.7 \pm 0.00^{\mathrm{aA}}$ & $5.18 \pm 0.12^{\mathrm{aA}}$ & $\begin{array}{c}3.48 \pm 0 \\
00^{\mathrm{aA}}\end{array}$ & $4.39 \pm 0.20^{\mathrm{aA}}$ & $<3$ & $3.44 \pm 0.04^{\mathrm{bA}}$ & $<3$ & $<3^{\mathrm{bB}}$ & $<3$ & $3.98 \pm 0.47^{\mathrm{bA}}$ & $<3$ \\
\hline
\end{tabular}

${ }^{*}$ Detection limit $=1.7 \log$ CFU $/ \mathrm{mL}$ for planktonic cells. SD not established. ${ }^{* *}$ Detection limit $=3 \log \mathrm{CFU} / \mathrm{cm}^{2}$ for sessile cells. SD not established. a,b,c Means in the same column followed by the same lowercase letter are not significantly different by the Tukey's test $(\mathrm{P} \geq 0.05)$.

${ }^{\mathrm{A}, \mathrm{B}}$ Means in the same row followed by the same uppercase letter (comparing $28{ }^{\circ} \mathrm{C} \mathrm{x} 45^{\circ} \mathrm{C}$ for vegetative cells and comparing $28{ }^{\circ} \mathrm{C} \mathrm{x} 45^{\circ} \mathrm{C}$ for spores) are not significantly different by the T-Student test $(\mathrm{P} \geq 0.05)$. The statistic test was applied separately for planktonic cells orange juice, sessile cells stainless steel and sessile cells rubber.

the highest biofilm formation of $A$. acidoterrestris $(\mathrm{P}<0.05)$ occurred after $48 \mathrm{~h}$ of contact at $28^{\circ} \mathrm{C}$ and 45 ${ }^{\circ} \mathrm{C}$, with a reduction after $72 \mathrm{~h}$, at both temperatures.

The low initial $A$. acidoterrestris population led to low sporulation efficiency of the microorganisms over time at 28 and $45^{\circ} \mathrm{C}$ (Table 1 ). Therefore, the presence of spores in the biofilm was not observed (count below the detection limit: $<3$ $\log \mathrm{CFU} / \mathrm{cm}^{2}$ ).

At high initial $A$. acidoterrestris population (Table 2) led to the biofilm formation on stainless steel after $4 \mathrm{~h}$ of contact at both $28^{\circ} \mathrm{C}$ and $45^{\circ} \mathrm{C}$. The highest biofilm formation was observed after $24 \mathrm{~h}$ of contact at $28^{\circ} \mathrm{C}$, although scores were not statistically different $(\mathrm{P} \geq 0.05)$ over time. At $45{ }^{\circ} \mathrm{C}$ after $8 \mathrm{~h}$ of contact the highest biofilm formation was observed (5.30 $\log \mathrm{CFU} / \mathrm{cm}^{2}, \mathrm{P}<0.05$ ). The biofilm formation was also observed on the natural food-grade rubber surface after a few hours, within $8 \mathrm{~h}$ and $4 \mathrm{~h}$ for 28 ${ }^{\circ} \mathrm{C}$ and $45^{\circ} \mathrm{C}$, respectively. On the natural food-grade rubber surface, the highest biofilm formation was observed at $28^{\circ} \mathrm{C}$ after $72 \mathrm{~h}$ of contact, with counts of $4.56 \log \mathrm{CFU} / \mathrm{cm} 2(\mathrm{P}<0.05)$. At $45^{\circ} \mathrm{C}$ the highest count was after $72 \mathrm{~h}$, however, there was no significant difference with the other times of contact $(\mathrm{P} \geq 0.05)$.

At high initial $A$. acidoterrestris population (5 $\log \mathrm{CFU} / \mathrm{mL}$ ), the planktonic cells counts in orange juice were higher after $4 \mathrm{~h}$ at both $28^{\circ} \mathrm{C}$ and $45^{\circ} \mathrm{C}$ and over time and the biofilm formation began after a few hours of contact with both stainless steel and natural food-grade rubber surfaces (Table 2). In addition, at high initial $A$. acidoterrestris populations, the sporulation in orange juice was observed after $4 \mathrm{~h}$ for the two temperatures under study, thus spore formation was detected in both biofilms from stainless steel and natural food-grade rubber surfaces. However, the spore count on the stainless steel surface decreased $(\mathrm{P}<0.05)$ after $24 \mathrm{~h}$ of contact.

In the present study we verified statistical difference between the temperatures tested. For example, on the stainless steel surface at low and high concentration at $24 \mathrm{~h}$ and $8 \mathrm{~h}$ contact, respectively, the vegetative cell counts of $A$. acidoterrestris were higher at $45^{\circ} \mathrm{C}$ than at $28^{\circ} \mathrm{C}(\mathrm{P}<0.05)$. For the natural food-grade rubber surface, at high concentrations, there was no statistical difference between the evaluated temperatures $(\mathrm{P} \geq 0.05)$.

The low initial microbial load inoculated in the orange juice at $28{ }^{\circ} \mathrm{C}$ allowed the adaptation of the bacteria with slow multiplication, thus taking more time for the biofilm formation and high microbial counts. This fact was confirmed by the planktonic cells counts in orange juice over time (Table 1). The initial (4 and $8 \mathrm{~h}$ ) planktonic cells counts were below $3 \log \mathrm{CFU} / \mathrm{mL}$, while the high planktonic cells counts (above 4-5 $\log \mathrm{CFU} / \mathrm{mL}$, $\mathrm{P}<0.05$ ) were only observed after $48 \mathrm{~h}$, precisely when the biofilm was formed. At $45^{\circ} \mathrm{C}$, high plankton cell counts were observed after $24 \mathrm{~h}(\mathrm{P}<0.05)$, when biofilm formation had already occurred.

Stainless steel surface was more propitious to biofilm of $A$. acidoterrestris formation at low 
Table 2 - Mean Alicyclobacillus acidoterrestris counts \pm SD of planktonic cells (log CFU/mL) and sessile cells $\left(\log \mathrm{CFU} / \mathrm{cm}^{2}\right)$ at initial inoculated load of $5 \log \mathrm{CFU} / \mathrm{mL}$.

\begin{tabular}{|c|c|c|c|c|c|c|c|c|c|c|c|c|}
\hline \multirow[t]{3}{*}{ Time (h) } & \multicolumn{4}{|c|}{ 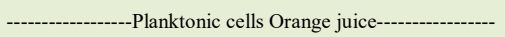 } & \multicolumn{4}{|c|}{ 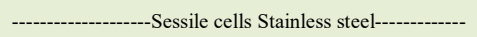 } & \multicolumn{4}{|c|}{ 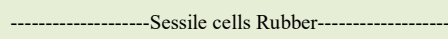 } \\
\hline & \multicolumn{2}{|c|}{ 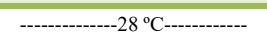 } & \multicolumn{2}{|c|}{---------45 ${ }^{\circ} \mathrm{C}-----------$} & \multicolumn{2}{|c|}{ 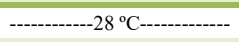 } & \multicolumn{2}{|c|}{ 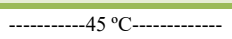 } & \multicolumn{2}{|c|}{--------28 ${ }^{\circ} \mathrm{C}---------$} & \multicolumn{2}{|c|}{---------45 ${ }^{\circ} \mathrm{C}-$} \\
\hline & $\begin{array}{l}\text { Vegetative } \\
\text { cells }\end{array}$ & Spores & $\begin{array}{l}\text { Vegetative } \\
\text { cells }\end{array}$ & Spores & $\begin{array}{l}\text { Vegetative } \\
\text { cells }\end{array}$ & Spores & $\begin{array}{l}\text { Vegetative } \\
\text { cells }\end{array}$ & Spores & $\begin{array}{l}\text { Vegetative } \\
\text { cells }\end{array}$ & Spores & $\begin{array}{l}\text { Vegetative } \\
\text { cells }\end{array}$ & Spores \\
\hline 4 & $5.40 \pm 1.06^{\mathrm{aB}}$ & $3.59 \pm 0.02^{\mathrm{bB}}$ & $6.35 \pm 0.08^{\mathrm{aA}}$ & $\begin{array}{c}4.45 \pm 0 . \\
13^{\mathrm{aA}}\end{array}$ & $3.30 \pm 0.17^{\mathrm{aA}}$ & $3.05 \pm 0.12^{\mathrm{a}}$ & $3.95 \pm 0.65^{\mathrm{bA}}$ & $<3^{* \mathrm{~b}}$ & $<3^{\mathrm{cB}}$ & $<3^{\mathrm{b}}$ & $4.13 \pm 1.52^{\mathrm{aA}}$ & $<3^{\mathrm{b}}$ \\
\hline 8 & $6.12 \pm 0.30^{\mathrm{aA}}$ & $4.45 \pm 0.13^{\mathrm{aA}}$ & $5.91 \pm 0.57^{\mathrm{aA}}$ & $\begin{array}{c}4.38 \pm 0 . \\
05^{\mathrm{aA}}\end{array}$ & $3.69 \pm 0.04^{\mathrm{aB}}$ & $\underset{\mathrm{A}}{3.59 \pm 1.00^{\mathrm{a}}}$ & $5.30 \pm 0.14^{\mathrm{aA} 2}$ & $\begin{array}{c}3.77 \pm 0 . \\
80^{\mathrm{aA}}\end{array}$ & $3.79 \pm 0.01^{\mathrm{bA}}$ & $<3^{\mathrm{b}}$ & $4.10 \pm 0.32^{\mathrm{aA} 1}$ & $<3^{\mathrm{b}}$ \\
\hline 24 & $5.71 \pm 0.56^{\mathrm{aA}}$ & $4.68 \pm 0.42^{\mathrm{aA}}$ & $5.49 \pm 0.30^{\mathrm{aA}}$ & $\begin{array}{c}4.58 \pm 0 . \\
20^{\mathrm{aA}}\end{array}$ & $4.29 \pm 0.02^{\mathrm{aA}}$ & $<3$ & $3.89 \pm 0.40^{\mathrm{bA}}$ & $<3^{\mathrm{b}}$ & $4.28 \pm 0.20^{\mathrm{a}, \mathrm{bA}}$ & $<3^{\mathrm{b}}$ & $4.37 \pm 0.18^{\mathrm{aA}}$ & $<3^{\mathrm{b}}$ \\
\hline 48 & $5.93 \pm 0.27^{\mathrm{aA}}$ & $5.16 \pm 0.06^{\mathrm{aA}}$ & $5.71 \pm 0.06^{\mathrm{aA}}$ & $\begin{array}{c}4.25 \pm 0 . \\
05^{\mathrm{aB}}\end{array}$ & $4.27 \pm 0.00^{\mathrm{aA}}$ & $<3$ & $4.10 \pm 0.44^{\mathrm{a}, \mathrm{bA}}$ & $<3^{b}$ & $4.01 \pm 0.19^{\mathrm{a}, \mathrm{bA}}$ & $\begin{array}{c}3.40 \pm 0 . \\
25^{\mathrm{aA}}\end{array}$ & $4.23 \pm 0.87^{\mathrm{aA}}$ & $\begin{array}{c}3.53 \pm 0 . \\
48^{\mathrm{AA}}\end{array}$ \\
\hline 72 & $6.00 \pm 0.00^{\mathrm{aA}}$ & $4.61 \pm 0.03^{\mathrm{aA}}$ & $5.64 \pm 0.05^{\mathrm{aA}}$ & $\begin{array}{c}3.74 \pm 0 . \\
39^{\mathrm{aB}}\end{array}$ & $3.82 \pm 0.45^{\mathrm{aA}}$ & $<3$ & $3.91 \pm 0.63^{\mathrm{bA}}$ & $<3^{\mathrm{b}}$ & $4.76 \pm 1.13^{\mathrm{aA}}$ & $\begin{array}{c}3.61 \pm 0 . \\
73^{\mathrm{aA}}\end{array}$ & $4.60 \pm 0.02^{\mathrm{aA}}$ & $\begin{array}{c}3.71 \pm 0 . \\
31^{\mathrm{AA}}\end{array}$ \\
\hline
\end{tabular}

"Detection limit $=3 \log \mathrm{CFU} / \mathrm{cm}^{2}$ for sessile cells. SD not established.

a,b,c, Means in the same column followed by the same lowercase letter are not significantly different by the Tukey's test $(\mathrm{P} \geq 0.05)$.

${ }^{\mathrm{A}, \mathrm{B}}$ Means in the same row followed by the same uppercase letter (comparing $28{ }^{\circ} \mathrm{C} \mathrm{x} 45^{\circ} \mathrm{C}$ for vegetative cells and comparing $28^{\circ} \mathrm{C} \times 45^{\circ} \mathrm{C}$ for spores) are not significantly different by the T-Student test $(\mathrm{P} \geq 0.05)$. The statistic test was applied separately for planktonic cells orange juice, sessile cells stainless steel and sessile cells rubber.

microbial load, however, at high microbial load, after $72 \mathrm{~h}$ of contact, natural food-grade rubber surface was more propitious.

The high initial load $(5 \log \mathrm{CFU} / \mathrm{mL})$ of $A$. acidoterrestris led to biofilm formation on the different surfaces more rapidly than low initial load (2 log CFU/mL). In this case, after $4 \mathrm{~h}$ of contact, biofilm formation has occurred, suggesting that hygiene procedures must be performed frequently. The microbial load can also affect the presence of spores in the biofilm formed, which was observed on both surfaces only at high initial loads of $A$. acidoterrestris.

\section{DISCUSSION}

The temperatures of $28^{\circ} \mathrm{C}$ and $45^{\circ} \mathrm{C}$ were selected in this study to represent the environment processing temperature and the ideal temperature of $A$. acidoterrestris growth, respectively (SMIT et al., 2011). The time interval was selected based on the equipment cleaning schedule of the orange juice industry.

Probably, the reduction in the biofilm count after $72 \mathrm{~h}$ on the food-grade rubber surface was due to the detachment of the biofilm cells, as the planktonic cell count in the orange juice remained high after 72 $\mathrm{h}$. This is worrisome because detachment can lead to food contamination or colonization of other regions, resulting in new biofilms (SIMÕES et al., 2010).

Among the two inoculated microbial load, $5 \log \mathrm{CFU} / \mathrm{mL}$ and $2 \log \mathrm{CFU} / \mathrm{mL}$, the highest biofilm formation of $A$. acidoterrestris was observed at higher microbial load, for both surfaces. Therefore, the higher the microorganism population, the greater the biofilm formation. PEÑA et al. (2014) found that the inoculation of $6 \log \mathrm{CFU} / \mathrm{mL}$ of Bacillus cereus in milk led to a higher biofilm formation when compared with the inoculation using a low microbial population ( $3 \log \mathrm{CFU} / \mathrm{mL}$ ), demonstrating the effect of the contamination level on the biofilm formation.

Regardless of the microbial species or surface analysed, the adhesion process may occur with maximum intensity at the optimum temperature growth range (MEIRA et al., 2012). Alicyclobacillus spp. can grow from 20 to $70{ }^{\circ} \mathrm{C}$, with the optimum temperature ranging from 42 to $60^{\circ} \mathrm{C}$ (SMIT et al., 2011).

It is worth mentioning that the spores adhere moreeasily to the stainless steel surface, due to their hydrophobic properties (RYU \& BEUCHAT, 2005), and the adhered spores become even more resistant to the cleaning procedures. Then, under favourable environmental conditions, the spores can germinate in vegetative cells and continue the multiplication process (ELHARIRY, 2011), being able to recontaminate the processed juice.

The great majority of the equipment surfaces in the juice processing industry is stainless steel, although this surface is considered smooth, it can wear away over time, with cracks and grooves and corrosion points, which also facilitate adhesion of the microorganism and subsequent biofilm formation (SIMÕES et al., 2010).

The natural food-grade rubber is a piece of the conveyor belts the fruits after the arrival at the factory. The rubber surface is usually affected by sanitizing procedures and, consequently, it wears away more easily, which favours the biofilm formation. In addition, rubber often has a porous and 
spongy structure, which facilitates the adhesion of microorganisms with subsequent biofilm formation. Therefore, these characteristics of the rubber should be evaluated before its use in the food industry. To date, the literature lacks information on biofilm formation of $\mathrm{A}$. acidoterrestris on rubber surfaces.

The biofilm formation of $A$. acidoterrestris in this study occurred at $28{ }^{\circ} \mathrm{C}$ and $45{ }^{\circ} \mathrm{C}$. It is worth noting that both temperatures are used in the equipment during the processing of orange juice, thus the poor sanitation can contribute to the biofilm formation. Both surfaces were suitable for biofilm formation of $A$. acidoterrestris. However, over time of contact, a higher biofilm formation was observed at high microbial load on the natural food-grade rubber surface, and at low microbial load on the stainless steel surface.

\section{ACKNOWLEDGEMENTS}

Coordenação de Aperfeiçoamento de Pessoal de Nível Superior (CAPES), Brasil - Finance code 001, for financial support.

\section{DECLARATION OF CONFLICT OF INTERESTS}

The authors declare no conflict of interest. The founding sponsors had no role in the design of the study; in the collection, analyses, or interpretation of data; in the writing of the manuscript, and in the decision to publish the results.

\section{AUTHORS' CONTRIBUTIONS}

All authors contributed equally for the conception and writing of the manuscript. All authors critically revised the manuscript and approved of the final version.

\section{REFERENCES}

ANJOS, M. M. et al. The resistance of Alicyclobacillus acidoterrestris spores and biofilm to industrial sanitizers. J Food Prot. 2013. 76:1408-1413. Available from: <https:// jfoodprotection.org/doi/pdf/10.4315/0362-028X.JFP-13-020> Accessed: Nov. 10, 2017. doi: 10.4315/0362-028X.JFP-13-020.

COSTERTON, J. W. etal. Microbial Biofilms. Annu Rev Microbiol. 1995. 49:711-745. Available from: <https://www.annualreviews. org/doi/abs/10.1146/annurev.mi.49.100195.003431>. Accessed: Jan. 15, 2018. doi: 10.1146/annurev.mi.49.100195.003431.

ELHARIRY, H. M. Attachment strength and biofilm forming ability of Bacillus cereus on green-leafy vegetables: Cabbage and lettuce. Food Microbiol. 2011. 28:1266-1274. Available from: $\quad<$ https://www.sciencedirect.com/science/article/pii/ S074000201100116X > . Accessed: Feb. 04, 2018. doi: 10.1016/j. fm.2011.05.004

FERNANDES, M. S. et al. Enterotoxigenic profile, antimicrobial susceptibility, and biofilm formation of Bacillus cereus isolated from ricotta processing. Int Dairy J. 2014. 38: 16-23. Available from: $\quad<$ https://www.sciencedirect.com/science/article/pii/ S0958694614000776>. Accessed: Mar. 25, 2018. doi: 10.1016/j. idairyj.2014.03.009.

FERREIRA, D. F. Manual do sistema Sisvar para análises estatísticas. 2008. (p. 66). Lavras, Brazil: UFLA.

HERIGSTAD B. et al. How to optimize the drop plate method for enumerating bacteria. Journal of Microbiological Methods 2001. 44: 121-129. Available from: <https://www.sciencedirect. com/science/article/pii/S0167701200002414>. Accessed: Mar. 04, 2018. doi: 10.1016/S0167-7012(00)00241-4.

MEIRA, Q. G. S. et al. Influence of temperature and surface kind on biofilm formation by Staphylococcus aureus from food-contact surfaces and sensitivity to sanitizers. Food Control. 2012. 25:469475. Available from: <https://www.sciencedirect.com/science/ article/pii/S0956713511005123>. Accessed: Dec. 05, 2017. doi:10.1016/j.foodcont.2011.11.030.

ORR, R. V. et al. Detection of guaiacol produced by Alicyclobacillus acidoterrestris in apple juice by sensory and chromatographic analyses and comparison with spore and vegetative cell populations. J Food Prot. 2000. 63:1517-1522. Available from: $<$ https://www.semanticscholar.org/paper/Detection-of-guaiacolproduced-by-Alicyclobacillus-OrrShewfelt/467afe80e871bb8d 8525691935db690dae3bde98>. Accessed: Dec. 13, 2018. doi: 10.4315/0362-028X-63.11.1517.

PEÑA, W. E. L. et al. A Modelling Bacillus cereus adhesion on stainless steel surface as affected by temperature, $\mathrm{pH}$ and time. Int Dairy. 2014. J34:153-158. Available from: <https://www. sciencedirect.com/science/article/pii/S0958694613002100>. Accessed: Nov. 08, 2018. doi: 10.1016/j.idairyj.2013.08.006

RYU, J. H. et al. Biofilm formation and sporulation by Bacillus cereus on a stainless steel surface and subsequent resistance of vegetative cells and spores to chlorine, chlorine dioxide, and a peroxyacetic acid-based sanitizer. J Food Prot. 2005. 68:2614-2622. Available from: <https://europepmc.org/article/ med/16355833>. Accessed: Jul. 30, 2018. doi: 10.4315/0362028X-68.12.2614.

SIMÕES, M. et al. A review of current and emergent biofilm control strategies. LWT - Food Sci. Technol. 2010. 43:573583. Available from: <https://www.sciencedirect.com/science/ article/pii/S0023643809003430>. Accessed: Dec. 10, 2017. doi: 10.1016/j.lwt.2009.12.008.

SMIT, Y. et al. Alicyclobacillus spoilage and isolation - A review. Food Microbiol. 2011. 28:331-349. Available from: $<$ https://www. sciencedirect.com/science/article/pii/S074000201000290X >. Accessed: Feb. 21, 2018. doi: 10.1016/j.fm.2010.11.008.

STEYN, C. E. et al.Occurrence of Alicyclobacillus in the fruit processing environment - A review. Int. J. Food Microbiol1. 2011. 47:1-11. Available from: <https://www.sciencedirect.com/ science/article/pii/S0168160511001413>. Accessed: Jan. 31, 2019. doi: 10.1016/j.ijfoodmicro.2011.03.004.

TIANLII, Y. et al. Spoilage by Alicyclobacillus bacteria in juice and beverage products: chemical, physical, and combined control methods. Compr Rev Food Sci Food Saf. 2014. 13:771797. Available from: <https://onlinelibrary.wiley.com/doi/ full/10.1111/1541-4337.12093>. Accessed: Dec. 05, 2018. doi: 10.1111/1541-4337.12093. 